\title{
シンポジウム $3-2$
}

\section{原発性免疫不全症における遺伝子解析}

東京医科歯科大学大学院 発生発達病態学分野

森尾友宏

原発性免疫不全症は, 自然免疫系あるいは獲得免疫系に関与する分子の異常により発症する免疫異常症でそ の多くは遺伝疾患である．今までに 250 以上の責任遺伝子が同定され，9つのカテゴリーに分類されている. 免疫不全症ではいわゆる易感染性の他に, 自己免疫疾患や悪性腫瘍を合併するもの, 自己免疫や炎症を主体と するもの, 特定の微生物に脆弱性を示すもの, など多彩な疾患群が含まれ，その解析から様々な疾患の分子基 盤が明らかになることが期待されている。

近年は，遺伝子解析技術の進歩と低価格化，基盤遺伝情報の充実などから，毎年 10 前後の新しい責任遺伝 子が明らかになっている，特に両親や同胞を含めた全エキソン解析からは PGM3，TWEAK， MALT1 などの異 常による新しい免疫不全症が次々と報告されている。ささに今まで知られていた表現型と異なる既知遺伝子異 常症（例えば EBVリンパ増殖症候群を呈するCORO1A 異常症）なども報告されている。また体細胞モザイク の高精度検出により，モザイクによる自己炎症性疾患なども容易に同定されるようになっている．

一方，複数以上の責任遺伝子変異が検出されたり，機能未知の遺伝子変異が捕まったりすることも稀ではな く, 遺伝子解析から機能解析, 機能検証につなげる方策について工夫・技術革新が必要である。ここでは私た ちの実際の解析データを示しながら, 原発性免疫不全症の遺伝子解析・遺伝子探索の現況と将来像について議 論を進めたい. 